\title{
Association between diet and polymorphisms in individuals with statin-controlled dyslipidaemia grouped according to oxidative stress biomarkers
}

\author{
Patrícia Borges Botelho', Cyntia Okoshi Fioratti², Marcelo Macedo Rogero ${ }^{3}$, \\ Lucia Pereira Barroso ${ }^{4}$, Marcelo Chiara Bertolami ${ }^{5}$, Inar Alves Castro, ${ }^{6, *}$
}

\begin{abstract}
${ }^{1}$ Department of Food and Experimental Nutrition, Faculty of Pharmaceutical Sciences, University of São Paulo, ${ }^{2}$ Department of Food and Experimental Nutrition, Faculty of Pharmaceutical Sciences, University of São Paulo, ${ }^{3}$ Department of Nutrition, School of Public Health, University of São Paulo, ${ }^{4}$ Statistics Department, Institute of Mathematics and Statistics, University of São Paulo, ${ }^{5}$ Dante Pazzanese Institute of Cardiology, São Paulo, ${ }^{6}$ Department of Food and Experimental Nutrition, Faculty of Pharmaceutical Sciences, University of São Paulo
\end{abstract}

\begin{abstract}
The objective of this study was to investigate whether differences in diet and in single-nucleotide polymorphisms (SNPs) found in paraoxonase-1 (PON-1), 3-hydroxy-3-methylglutaryl-coenzyme A reductase (HMGCR), cholesterol ester transfer protein (CETP) and apolipoprotein E (APOE) genes, are associated with oxidative stress biomarkers and consequently with susceptibility of low-density cholesterol (LDL) to oxidation. A multivariate approach was applied to a group of 55 patients according to three biomarkers: plasma antioxidant activity, malondialdehyde and oxidized LDL (oxLDL) concentrations. Individuals classified in Cluster III showed the worst prognoses in terms of antioxidant activity and oxidative status. Individuals classified in Cluster I presented the lowest oxidative status, while individuals grouped in Cluster II presented the highest levels of antioxidant activity. No difference in nutrient intake was observed among the clusters. Significantly higher $\gamma$ - and $\delta$-tocopherol concentrations were observed in those individuals with the highest levels of antioxidant activity. No single linear regression was statistically significant, suggesting that mutant alleles of the SNPs selected did not contribute to the differences observed in oxidative stress response. Although not statistically significant, the p value of the APO E coefficient for oxLDL response was 0.096, indicating that patients who carry the TT allele of the APO E gene tend to present lower plasma oxLDL concentrations. Therefore, the differences in oxidative stress levels observed in this study could not be attributed to diet or to the variant alleles of PON-1, CETP, HMGCR or APO E. This data supports the influence of $\gamma$-tocopherol and $\delta$-tocopherol on antioxidant activity, and highlights the need for further studies investigating APO E alleles and LDL oxidation.
\end{abstract}

Uniterms: Diet. Oxidative stress/biomarkers. Single-nucleotide polymorphism (SNPs). Lipoproteins/ oxidation. Statins. Apolipoprotein E.

O objetivo deste estudo foi investigar se diferenças na dieta e em polimorfismos de nucleotídeos únicos (SNPs) encontrados no gene da paraoxonase 1 (PON-1), da 3-hidroxi-3-metilglutaril-coenzima A reductase (HMGCR), da proteína de transferência de ésteres de colesterol (CETP) e da apolipoproteina E (APOE) estariam associadas com biomarcadores do estresse oxidativo e, consequentemente, com a suscetibilidade da LDL à oxidação. Técnicas da estatística multivariada foram aplicadas a um grupo de 55 pacientes usando 3 biomarcadores: atividade antioxidante plasmática, concentrações de malondialdeído e LDL oxidada. Indivíduos classificados no cluster III apresentaram um prognóstico negativo em termos de atividade antioxidante e estado oxidativo. Os indivíduos agrupados no cluster I apresentaram o mais baixo nível de estado oxidativo, enquanto que indivíduos no cluster II apresentaram os mais altos níveis de atividade antioxidante. Nenhuma diferença na ingestão de nutrientes foi observada entre os clusters.

\footnotetext{
*Correspondence: I. A. Castro. Departamento de Alimentos e Nutrição Experimental, Faculdade de Ciências Farmacêuticas - USP. Av. Lineu Prestes, 580, B14 - 05508-900 - São Paulo - SP, Brazil. E-mail: inar@usp.br
} 


\begin{abstract}
Concentrações estatísticamente mais altas de $\gamma$ - e $\delta$-tocoferol foram observadas em indivíduos com mais altos níveis de atividade antioxidante. A regressão linear aplicada não foi estaticamente significativa, sugerindo que os alelos mutantes dos SNPs selecionados não contribuíram para as diferenças nos níveis de estresse oxidativo. Embora não tenha sido estatisticamente significativa, o valor da probabilidade associado ao coeficiente da relação entre ApoE e oxLDL foi de 0,096, indicando que pacientes que carregam o alelo TT da ApoE tendem a apresentar menores concentrações plasmáticas de LDL oxidada. Portanto, as diferenças no estresse oxidativo observadas em nosso estudo não puderam ser atribuídas à dieta e alelos variantes de PON-1, CETP, HMGCR ou ApoE. Nossos dados suportam a influência $\gamma$ - tocoferol e $\delta$-tocoferol na atividade antioxidante e reforçam a necessidade de mais pesquisas que investiguem a relação entre alelos da Apo E e a oxidação da LDL.
\end{abstract}

Unitermos: Dieta. Estresse oxidativo/biomarcadores. Polimorfismo de nucleotídeo único (SNPs). Lipoproteína/oxidação. Estatinas. Apolipoproteina E.

\section{INTRODUCTION}

Atherosclerosis is clinically defined as a subacute inflammation of the vessel wall, characterized by infiltration of macrophages and T cells in the artery wall (Libby et al., 2011). It is widely accepted that the atherosclerotic process begins with LDL oxidation (Steinberg et al., 1989; Witztum and Steinberg, 2001). Apolipoprotein B and the lipid fraction of LDL, suffer oxidation due to excess reactive species, contributing to oxidative stress (Kontush et al., 2003; Stephens et al., 2008). In fact, modification of LDL seems to be the key determinant of lipid uptake by macrophages (Parthasarathy et al., 2008). Thus, chronic elevation of both reactive species and LDL circulating in the arteries can strongly contribute to the progression of atherosclerosis.

Several specific proteins have been linked to LDL concentration and its susceptibility to oxidation. The focus of this study was atherosclerosis and its correlation with oxidative stress in this specific population. Therefore, SNPs associated with genes that encode proteins involved with both processes, the amount of LDL and its susceptibility to oxidation by reactive species, such as cholesterol ester transfer protein (CETP), 3-hydroxy-3-methylg1utaryl-coenzyme A reductase (HMGCR), paraoxonase isoform $1(\mathrm{PON}-1)$ and apolipoprotein $\mathrm{E}$ (ApoE) were selected. The transport of cholesterol esters from HDL to VLDL depends on CETP activity (Thompson et al., 2008). Low CETP activity and concentrations have been associated with elevated HDL (Zee et al., 2002; Van Acker et al., 2008). Statins, which inhibit HMGCR, block the rate-limiting step in cholesterol synthesis, induce mRNA transcription for the LDL receptor (Morikawa et al., 2000), and up-regulate LDL binding sites (Li et al., 2003), thus reducing the risk of coronary artery disease by around $30 \%$ (Zee et al., 2002). HDL exerts its protective effects through a number of mechanisms, including cholesterol reverse transport, inhibition of LDL oxidation and reduction of the inflammatory response (Proudfoot et al., 2009). Plasma HDL, especially the small and dense HDL3, contains antioxidant enzymes with diverse substrate specificity, such as PON-1, platelet-activating factor acetylhydrolase (PAF$\mathrm{AH}$ ), lecithin-cholesterol acyltransferase (LCAT) and apolipoproteins that can delay or inactivate the formation of oxidized lipids in LDL. Apolipoprotein (ApoE) plays an important role in lipid metabolism, thus mediating the binding and uptake of lipoproteins, and influencing cholesterol homeostasis (Mahley, 1988; Kolovou et al., 2009).

Gene-environment interactions may influence oxidative stress, LDL oxidation and subsequent cardiovascular disease (Stephens et al., 2008). Exogenous factors such as nutrient intake also affect LDL concentrations and oxidation susceptibility. From a nutrigenomic point of view, nutrients and bioactive food components can interfere with gene expression (Kauwell, 2005). From a nutrigenetic perspective, any change in the nucleotide sequence of genes that encode proteins associated with oxidative stress may explain individual variation in the response to the same stimulus, resulting in different risks for the development of diet-related diseases. Thus, a better understanding of nutrigenomic and nutrigenetic effects will allow medical professionals to further optimize diet according to individual genetic profile.

According to Stephens et al. (2008), relatively few publications have examined the association between gene variants and biochemical markers of oxidative stress in vivo. In a previous study, Botelho et al. (2010) observed no correlation between oxidative stress, as measured by four biomarkers, and dietary intake in individuals with dyslipidaemia controlled by statins. In this study, we investigated whether there was difference in the proportion of certain single nucleotide polymorphisms (SNPs) related to the lipid metabolism genes among clusters containing individuals with different oxidative stress conditions. 


\section{MATERIALS AND METHODS}

\section{Chemicals}

All reagents were purchased from Sigma Chemical Co. (St Louis, MO, USA), Merck (Darmstadt, Germany) or Invitrogen (Carlsbad, CA, USA). All of the reagents used in the experiments were of analytical grade. Aqueous solutions were prepared with ultra-pure Milli-Q water (Millipore Ind. Com. Ltd, São Paulo, Brazil). Organic solvents were of high performance liquid chromatography (HPLC) grade.

\section{Subjects}

Subjects were recruited from the patient data bank at the Dante Pazzanese Institute of Cardiology (São Paulo, Brazil). From the hospital database containing 1056 patients, 82 individuals, including both males and females, were recruited to participate in this study. Patients were included if they were between 30 and 80 years old, had a BMI (body mass index) of between 18.5 and $29.9 \mathrm{~kg} / \mathrm{m}^{2}$, and had been taking statins (simvastatin or atorvastatin 3-hydroxy-3-methyl-glutaryl-CoA reductase inhibitors) at doses ranging from 10 to $80 \mathrm{mg} /$ day for at least 6 months. Patients were excluded from the study if they were pregnant or breast-feeding; if they had diabetes, kidney disease, endocrine disease, liver disease or a personal history of myocardial infarction or stroke; or if they were taking hormone treatment for menopause. Of the 82 individuals initially recruited, 55 participated in the study. The remaining 27 volunteers were dropped from the study because they did not have their blood collected on time. This study was conducted according to the guidelines laid down in the Declaration of Helsinki, and all procedures involving human patients were approved by the Ethics Committee of the Pharmaceutical Science Faculty and the Dante Pazzanese Institute of Cardiology. Written, informed consent was obtained from all patients.

\section{Dietary intake}

Dietary intake was assessed using a 3-day food register repeated twice. This food register provided information such as the type and amount of food eaten throughout the day, over 6 days. The macro- and micronutrient contents of the daily food consumption of each patient were obtained by the Nutriquanti ${ }^{\circledR}$ software program. This software was based on information from the United States Department of Agriculture's database. Thus, the 6-day average intake of macronutrients was assessed, including carbohydrates, proteins and lipids (total, saturated, monounsaturated and polyunsaturated fats and cholesterol), along with some micronutrients, such as iron, manganese, zinc and vitamin C.

\section{Measurement of biochemical variables}

Enzymatic colorimetric methods were used to determine total serum cholesterol (Liquiform Cat. 76, using cholesterol esterase, cholesterol oxidase and peroxidase), HDL-cholesterol (Cat. 13, using precipitation with phosphotungstic acid and $\mathrm{MgCl}_{2}$ ) and triacylglycerol (GPO-ANA, Cat. 59, using glycerol 3-phosphate oxidase) concentrations. LDL-cholesterol concentrations were estimated using the Friedewald formula (Friedwald et al. 1972).

\section{Oxidized-LDL (oxLDL) measurement}

A sandwich ELISA methodology was used to evaluate the plasma concentration of oxLDL by spectrophotometry using a microplate reader (Spectra Count Microplate Photometer, Packard Instruments Company, Downers Grove, IL, USA) as described by Faulin et al. (2008). A calibration curve was carried out on each plate, using oxLDL extracted from human plasma by FPLC (Fast Protein Liquid Chromatography) as a standard $(0.625-20,000 \mu \mathrm{g} / \mathrm{mL})$. The results were expressed as U/1, with 1 unit representing $1.0 \mathrm{~g} / \mathrm{L}$ oxidized Apo B.

\section{Plasma tocopherol concentration}

Measurements of $\alpha$-, $\gamma$ - and $\delta$-tocopherol were performed in plasma samples by high-performance liquid chromatography (HPLC) according to the protocol described by Siluk et al. (2007). A standard curve was prepared using 10 - $30 \mu \mathrm{g} / \mathrm{mL}$ of $\alpha$-tocopherol, 0.02 - $4 \mu \mathrm{g} / \mathrm{mL}$ for $\gamma$-tocopherol and $0.01-1 \mu \mathrm{g} / \mathrm{mL}$ for $\delta$-tocopherol. Calibration curves were calculated using working solutions of a mixture of analytes, and results expressed as $\mu \mathrm{g} / \mathrm{mL}$.

\section{Total antioxidant activity}

Total antioxidant activity in serum and plasma samples was measured using three assays: 2,2-diphenyl1-picrylhydrazyl radical (DPPH) assay, ferric-reducing ability power (FRAP) and oxygen-radical absorbance capacity (ORAC). The DPPH method was carried out as previously described by Chrzczanowicz et al. (2008), whereas FRAP was performed according to Benzie and Strain (1999). The ORAC assay was performed in plasma 
samples according to Prior et al. (2003). A calibration curve was prepared using Trolox solution at concentrations ranging from 6.5 to $50 \mu \mathrm{mol} / \mathrm{L}$ for the lipophilic assay and 6.5 to $100 \mu \mathrm{mol} / \mathrm{L}$ for the hydrophilic assay.

\section{Plasma malondialdehyde (MDA) concentration}

The MDA concentrations in the plasma samples were determined by reverse phase HPLC (Agilent Technologies 1200 series; Santa Clara, CA, USA) according to Cheng et al. (2008), using a thiobarbituric acid (TBA) derivatization. A standard curve was prepared using malondialdehyde tetrabutylammonium salt (MDA) at concentrations ranging from 0.5 to $5.0 \mu \mathrm{mol} / \mathrm{L}$. Results were expressed as $\mu \mathrm{mol} / \mathrm{L}$ of MDA.

\section{DNA isolation and genotyping}

DNA was extracted from whole blood by the salting out method described by Miller et al. (1988). After extraction, DNA was visualized after electrophoresis through a $1 \%$ agarose gel, and the DNA concentration was measured using a Nanodrop 8000 spectrophotometer (Thermo Scientific, Waltham, MA, USA). Genotyping of selected SNPs [PON-1 584G $\rightarrow$ A (Gln192Arg); CETP Taq $\mathrm{IB} \mathrm{C} \rightarrow \mathrm{T}(\mathrm{rs} 708272) ; \mathrm{HMGCR} 29 \mathrm{~T} \rightarrow \mathrm{G}(\mathrm{rs} 17238540)$ and $\mathrm{ApoE}-219 \mathrm{G} \rightarrow \mathrm{T}$ (rs405509)] was performed using allele-specific polymerase chain reaction (ASPCR) or the amplification refractory mutation system (ARMS) (Newton et al., 1989). Amplification products were detected via fluorescence resonance energy transfer (FRET) analysis according to Livak et al. (1995).

\section{Statistical analysis}

Results were expressed as mean and pooled SD. Principal component analysis (PCA) was applied to classify the individuals $(n=55)$ according to their oxidative conditions based upon their oxidative stress biomarkers. The data matrix for independent variables expressed in different units was prepared by adopting biomarkers as columns and individuals as rows. Tree-clustering analysis was used to group individuals according to similarity based upon the five biomarkers of oxidative stress (DPPH, ORAC, FRAP, MDA and oxLDL). This analysis was based on Ward's method and Euclidean distances. Main-effects ANOVA, followed by Tukey's HSD post-hoc test, was used to evaluate the differences among the three generated clusters. Homogeneity of variances was checked by Hartley's test. Polymorphisms, i.e., the allele variant versus wild type allele, were admitted as independent variables, and linear models were fitted to the following responses: $1^{\text {st }}$ Principal Component (PC1), MDA and oxLDL. ANOVA was applied to evaluate the significance of the three models. P values $<0.05$ were considered to indicate significance. Statistical analyses were performed using STATISTICA 7.1 software (Statsoft Inc., Tulsa, OK, USA) and MINITAB 15 (Minitab Inc., State College, PA, USA).

\section{RESULTS}

In this study, in addition to tocopherol concentrations, five oxidative biomarkers were also evaluated in this population: antioxidant activity (DPPH, FRAP, ORAC), MDA and oxLDL (Table I). Significant linear correlations were observed between antioxidant activity in plasma measured by ORAC and FRAP $(\mathrm{r}=+0.57, \mathrm{p}<0.001)$ and by ORAC and DPPH $(+0.43, \mathrm{p}=0.001)$. Notably, the ORAC assay was performed one year after the FRAP and DPPH measurements were taken. Thus, our results suggest that, at least for comparison purposes, ORAC can be used to evaluate plasma samples stored at $-80{ }^{\circ} \mathrm{C}$ for long periods of time.

TABLE I - Oxidative stress biomarkers of subjects $(\mathrm{n}=55)$

\begin{tabular}{lcc}
\hline Variables & Mean Values & SD \\
\hline MDA $(\mu \mathrm{mo} / \mathrm{L})$ & 1.40 & 0.36 \\
FRAP $(\mu \mathrm{mol} / \mathrm{L})$ & 885.00 & 177 \\
DPPH $(\%$ of inhibition $)$ & 4.5 & 1.3 \\
oxLDL $(\mathrm{U} / \mathrm{L})$ & 19.61 & 20.24 \\
ORAC $($ hydro $)(\mu \mathrm{mol} \mathrm{TE} / \mathrm{L})$ & $1,704.36$ & 292.59 \\
ORAC $($ lipo $)(\mu \mathrm{mol} \mathrm{TE} / \mathrm{L})$ & 428.18 & 108.12 \\
ORAC $($ total $)(\mu \mathrm{mol} \mathrm{TE} / \mathrm{L})$ & $2,118.00$ & 311.98 \\
$\alpha$-tocopherol $(\mu \mathrm{g} / \mathrm{mL})$ & 11.28 & 2.49 \\
$\gamma$-tocopherol $(\mu \mathrm{g} / \mathrm{mL})$ & 1.23 & 0.55 \\
$\delta$-tocopherol $(\mu \mathrm{g} / \mathrm{mL})$ & 0.11 & 0.08 \\
\hline
\end{tabular}

MDA malondialdehyde ; FRAP Ferric Reducing Anti-oxidant Power; DPPH 2.2-diphenyl-1-picrylhydrazyl radical; oxLDL oxidized low density lipoprotein; ORAC oxygen radical absorbance capacity

Multivariate analysis was performed using five oxidative biomarkers as active variables (ORAC, DPPH, FRAP, oxLDL and MDA). Cluster analysis was applied to classify the individuals $(\mathrm{n}=55)$ based on these five biomarkers of oxidative stress. This analysis suggested that patients could be classified into three groups (clusters). Afterward, the other variables measured in this study were 
compared among the clusters. Projection of these groups onto the factor-plane ( $1 \times 2)$ was performed by submitting the matrix of data to Principal Component Analysis (PCA) (Figure 1).

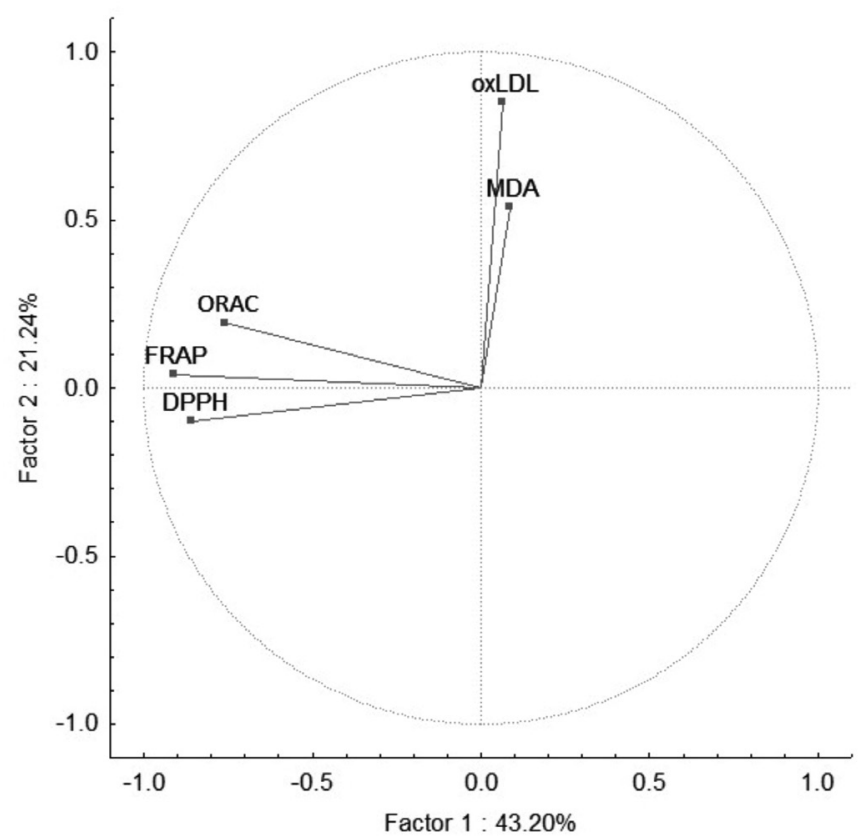

FIGURE 1- Projection of the variables (oxidative stress biomarkers) on the factor-plane ( $1 \times 2)$.

The contribution of each variable to the principal components (Table II) showed that antioxidant activity was responsible for the separation of individuals in the first principal component (PC1); oxLDL separated individuals in the second component (PC2), whereas MDA was well represented in the third component (PC3).

TABLE II - Factor coordinates of variables, based on correlations

\begin{tabular}{lccc}
\hline Variables & PC 1 & PC 2 & PC 3 \\
\hline ORAC & $\mathbf{- 0 . 7 6}$ & 0.19 & 0.15 \\
MDA & 0.08 & 0.54 & $\mathbf{- 0 . 8 4}$ \\
FRAP & $\mathbf{- 0 . 9 1}$ & 0.04 & -0.01 \\
DPPH & $\mathbf{- 0 . 8 6}$ & -0.10 & -0.16 \\
oxLDL & 0.06 & $\mathbf{0 . 8 5}$ & 0.48 \\
\hline
\end{tabular}

PC principal component; MDA malondialdehyde ; FRAP Ferric Reducing Antioxidant Power; DPPH 2.2-diphenyl-1picrylhydrazyl radical; oxLDL oxidized low density lipoprotein; ORAC oxygen radical absorbance capacity

Characterization of the three clusters according to nutrient intake, blood biochemistry and PON-1, HMGCR, CETP and ApoE polymorphisms is shown in Figure 2.
No difference in nutrient intake between the clusters was observed $(\mathrm{p}<0.05)$. Although the patients showed a large age range, no significant correlations were observed between subjects' age, oxidative biomarkers and nutrient intake. For this reason, Figure 2 was designed to show that individuals with the same nutrient intake exhibited differences in oxidative stress biomarkers.

The dietary intake values in Figure 2 represent the average intake of the 55 subjects. Individuals in Cluster III showed the worst prognoses in terms of antioxidant activity and oxidative status. Cluster I contained individuals with intermediate antioxidant activity, while individuals in Cluster II showed the highest antioxidant activity. No differences in plasma lipoprotein concentrations were observed between the clusters. However, the highest plasma $\gamma$-tocopherol and $\delta$-tocopherol concentrations were observed in individuals who also exhibited the highest antioxidant activity (Cluster II).

The allelic distributions of all four polymorphisms characterized in this study were evaluated by the Chisquare test and were in Hardy-Weinberg equilibrium. Tables III, IV and V depict the effects caused by each polymorphism on mean PC1, MDA and oxLDL responses, respectively. PC1 includes measurements for ORAC, DPPH and FRAP, representing an "antioxidant capacity" response. No linear regression model indicated a statistically significant effect for a particular polymorphism, and all coefficients had $\mathrm{p}$-values higher than 0.05 . The calculated determination coefficients $\left(\mathrm{R}^{2}\right)$ were also low $(<12 \%)$, indicating that the mutant alleles could not explain the variation in these results. Although no statistical significance was observed, the p-value of the ApoE coefficient in the oxLDL response was 0.096, suggesting that patients carrying the TT allele in the ApoE gene tend to exhibit reduced plasma oxLDL concentrations.

\section{DISCUSSION}

The individuals with statin-controlled dyslipidaemia presented different profiles of total antioxidant activity (PC1) and oxidative status (MDA and oxLDL), but these differences could not be associated with their nutrient intake, plasma lipoprotein concentration or polymorphisms in CETP, HMGCR, PON-1 and ApoE proteins. The CETP, HMGCR and ApoE polymorphisms were selected in this study due to their strong association with lipoprotein metabolism and increased availability of LDL as a substrate for oxidation. For example, a reduction in CETP activity implies an increase in HDL, reducing the risk of LDL for oxidation. Among the SNPs investigated in this study, PON-1 $(584 \mathrm{G} \rightarrow \mathrm{A})$ appears to be the most 


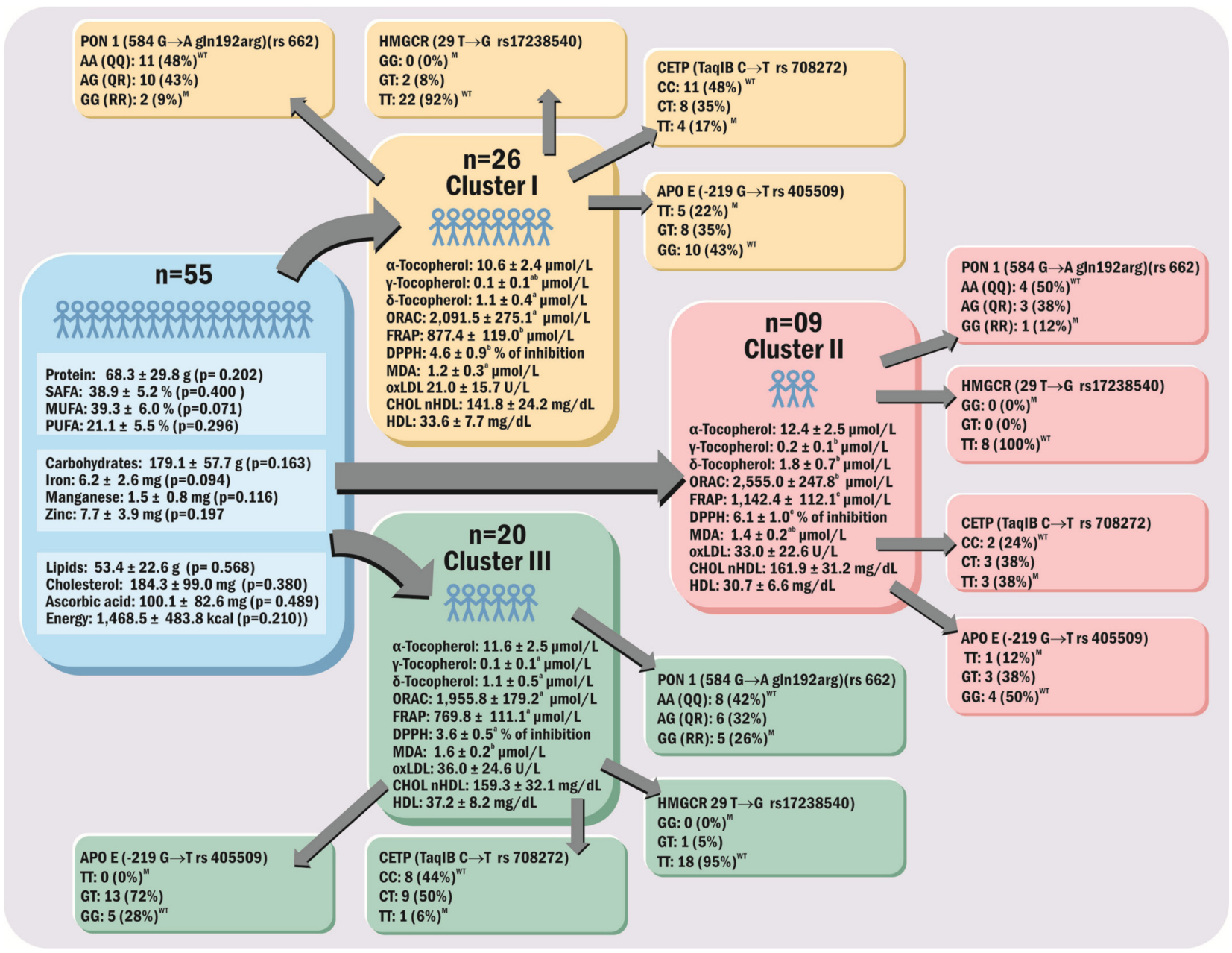

FIGURE 2 - Classification of studied individuals $(n=55)$ according to cluster analysis and characterization of the three clusters based on nutrient intake, blood biochemistry and polymorphisms in PON-1, HMGCR, CETP and APO E genes. SAFA - saturated fatty acids; MUFA - monounsaturated fatty acids; PUFA - polyunsaturated fatty acids; ORAC - oxygen radical absorbance capacity; FRAP - ferric-reducing antioxidant power; DPPH - 2,2-diphenyl-1-picrylhydrazyl radical; MDA - malondialdehyde; oxLDL oxidized low density lipoprotein; HDL - high density lipoprotein; PON1 - paraoxonase 1; HMGCR - 3-hydroxy-3-methylglutarylcoenzyme A reductase; CETP - cholesterol ester transfer protein; ApoE - apolipoprotein E; M - mutant gene; WT - wild-type. P values obtained by ANOVA: $\alpha$-tocopherol $(\mathrm{p}=0.316), \gamma$-tocopherol $(\mathrm{p}=0.006), \delta$-tocopherol $(\mathrm{p}=0.003)$, ORAC $(\mathrm{p}=0.001)$, FRAP $(\mathrm{p}<0.001)$, DPPH $(\mathrm{p}=0.004), \operatorname{MDA}(\mathrm{p}=0.052)$, oxLDL $(\mathrm{p}=0.145)$ and CHOL nHDL $(\mathrm{p}=0.208)$. Means for the same variable with different superscript letters are significantly different, $\mathrm{p}<0.05$.

TABLE III - Coefficients of the linear models adjusted to Principal Component 1 response (antioxidant activity response)

\begin{tabular}{lccc}
\hline Predictor & Coefficient & SE & P value \\
\hline Constant & 0.2019 & 0.5256 & 0.703 \\
PON1 & -0.2275 & 0.4571 & 0.621 \\
CETP & 0.3768 & 0.4843 & 0.441 \\
HMGCR & -0.7173 & 0.9230 & 0.441 \\
ApoE & -0.3687 & 0.4677 & 0.435 \\
\hline
\end{tabular}

PON 1 Paraoxonase 1 ; CETP Cholesteryl Ester Transfer Protein; HMGCR 3-hydroxy-3-methylglutaryl-coenzyme A reductase ; ApoE Apolipoprotein E; SE Standard Error
TABLE IV - Coefficients of the linear models adjusted to oxLDL response

\begin{tabular}{lccc}
\hline Predictor & Coefficient & SE & P value \\
\hline Constant & $41,925.0$ & $7,494.0$ & 0.000 \\
PON1 & $-3,755.0$ & $6,518.0$ & 0.568 \\
CETP & $-4,932.0$ & $6,905.0$ & 0.479 \\
HMGCR & $-13,689.0$ & $13,161.0$ & 0.304 \\
ApoE & $-11,373.0$ & $6,669.0$ & 0.096 \\
\hline
\end{tabular}

PON 1 Paraoxonase 1 ; CETP Cholesteryl Ester Transfer Protein; HMGCR 3-hydroxy-3-methylglutaryl-coenzyme A reductase ; ApoE Apolipoprotein E; SE Standard Error 
TABLE V - Coefficients of the linear models adjusted to MDA response

\begin{tabular}{lccc}
\hline Predictor & Coefficient & SE & P value \\
\hline Constant & 1.2257 & 0.1019 & 0.000 \\
PON1 & 0.0852 & 0.0886 & 0.341 \\
CETP & 0.0916 & 0.0939 & 0.335 \\
HMGCR & 0.1877 & 0.1789 & 0.300 \\
ApoE & 0.1081 & 0.0906 & 0.240 \\
\hline
\end{tabular}

PON 1 Paraoxonase 1 ; CETP Cholesteryl Ester Transfer Protein; HMGCR 3-hydroxy-3-methylglutaryl-coenzyme A reductase ; ApoE Apolipoprotein E; SE Standard Error

relevant because the PON-1 enzyme protects lipoproteins against oxidative stress by metabolizing lipid peroxides. In addition, the significant differences between biomarkers across clusters could be interpreted as a lack of adaptive response to oxidative stress of these individuals (Crawford and Davies, 1994), such as increased activity or expression of antioxidant enzymes.

This study demonstrated the advantages of using a multivariate statistical approach to investigate associations between polymorphisms and oxidative stress. Firstly, many responses can be grouped by multivariate techniques into principal components. Secondly, it is possible to measure the direct effects of wild-type and mutant alleles on these responses or on the principal components. A third advantage of this statistical treatment is that interactions among polymorphisms can be identified and discussed. The lack of significance of those models including polymorphisms and oxidative response observed in this study may be attributed to the low number of individuals in each genetic subgroup. According to Kajinami et al. (2004), generating a sample size large enough for adequate statistics is a key issue for pharmacogenetic studies, and this situation may also apply to nutrigenetics research. Although the number of patients included in this study is considered low, it was sufficient to demonstrate how multivariate techniques can be applied to classify individuals according to several parameters and then to determine differences in the proportion of SNPs among the groups formed. This is the first time that the procedure has been used to evaluate the presence of polymorphisms in patients before their classification according to susceptibility to oxidation.

However, a real absence of association between the selected SNPs and the oxidative biomarkers cannot be excluded. CETP concentration is associated with the common Taq $1 \mathrm{~B}$ polymorphism, and carriers of the $\mathrm{B} 2$ allele exhibit lower plasma CETP levels, higher HDL and reduced risk for coronary heart disease (Boekholdt et al., 2005; Thompson et al., 2008; Van Acker et al., 2008). However, other studies of different CETP polymorphisms, such as $-629 \mathrm{C}>\mathrm{A}$ and Taq IB, did not support this association (Lu et al., 2003; Tanrikulu et al., 2009). Overall, the influence of CETP on the anti-atherogenic properties of HDL in vivo must be investigated. Individuals who are heterozygous for the $\mathrm{G}$ allele of rs 17238540 at the HMGCR gene may respond less well to statin therapy in terms of total cholesterol and triglyceride levels (Chasman et al., 2004; Donelly et al., 2008). The majority of individuals evaluated in the present study were wild-type allele carriers. Therefore, the influence of the mutant allele could not be evaluated here.

Paraoxonase isoform 1 (PON-1) is a glycoprotein expressed primarily in the liver and contributes to HDL antioxidant activity (Bhattacharyya et al., 2008; Rainwater et al., 2009). PON-1 is able to delay LDL oxidation by hydrolyzing oxidized phospholipids and hydroperoxides, playing an anti-atherogenic role ( $\mathrm{Ng}$ et al., 2005). The Q192R SNP (rs662) in the PON-1 gene replaces a glutamine residue with an arginine residue at position 192 in the amino acid chain. This substitution can influence the lipoperoxide hydrolyzing activity of PON-1 and its antioxidant activity, where this polymorphism is associated with coronary artery disease, stroke and familial hypercholesterolemia ( $\mathrm{Ng}$ et al., 2005). However, Robertson et al. (2003) suggested that the PON-1 polymorphisms may have little or no effect on CVD risk in healthy subjects unless other factors, such as diabetes, are present.

Our results showed a tendency $(p=0.096)$ of the ApoE allele $(\mathrm{T})$ to reduce oxLDL concentration. Comparison of the linear regression coefficients with the cluster analysis suggests that this result may be associated with the homozygous condition (TT). Lambert et al. (2000) reported that the -219T allele of ApoE (also called Th1/ E47cs) was associated with a significant reduction in myocardial infarction. This effect was shown be independent of the presence of other Apo E mutations, including the $\varepsilon 2 /$ $\varepsilon 3 / \varepsilon 4$ polymorphisms (Ye et al., 2003). Viiri et al. (2005) observed that the more common -219G genotype $(\mathrm{G})$ was found more frequently in a group with high plasma VLDL, ApoE and triacylglycerol concentrations and was associated with lower plasma HDL concentrations. Viitanen et al. (2001) demonstrated that the $-219 \mathrm{~T}$ allele tended to influence total or LDL cholesterol levels and was related to atherosclerosis in coronary arteries.

This analysis revealed a significant association between high $\gamma$-tocopherol and $\delta$-tocopherol plasma concentrations and the highest antioxidant activity. Several studies have investigated the effects of $\alpha$-tocopherol supplementation on oxidative biomarkers. Although an inverse correlation has been observed between elevated 
$\alpha$-tocopherol plasma levels and decreased oxidation biomarkers, no practical effects of $\alpha$-tocopherol status and cardiovascular events have been demonstrated (Vivekananthan et al., 2003; Roberts et al., 2007). According to Devarej et al. (2008), $\gamma$-tocopherol supplementation alone significantly reduces biomarkers of oxidative stress, plasma MDA and lipid peroxides, and is more potent than $\alpha$-tocopherol for decreasing nitrosative stress. After a thorough review of the effect of tocopherols on heart disease, Jialal and Devaraj (2005) recommended that serious consideration should be given to the use of $\gamma$-tocopherol supplementation to reduce biomarkers of oxidative stress.

\section{CONCLUSION}

In conclusion, this study presents a new statistical approach to evaluating polymorphisms and oxidative biomarkers in humans. Based on the data presented, differences in oxidative status between the individuals selected in the study cannot be attributed to diet or lipoprotein profile changes nor to the presence of SNPs in the PON-1, CETP, HMGCR and ApoE genes involved in lipoprotein metabolism. However, the study results corroborate the influence of $\gamma$-tocopherol and $\delta$-tocopherol on antioxidant activity in humans and reinforce the need for further research investigating APO E alleles and LDL oxidation.

\section{ACKNOWLEDGEMENTS}

This study was financially supported by FAPESP (07/01476-8; 08/00482-7 and 08/10826-5).

\section{CONFLICT OF INTEREST}

The authors declare no conflict of interest.

\section{REFERENCES}

BENZIE, I.F.; STRAIN, J.J. Ferric reducing/antioxidant power assay: direct measure of total antioxidant activity of biological fluids and modified version for simultaneous measurement of total antioxidant power and ascorbic acid concentration. Methods Enzymol., v.299, p.15-27, 1999.

BHATTACHARYYA, T.; NICHOLLS, S.J.; TOPOL, E.J.; ZHANG, R.; YANG, X.; SCHMIDT, D.; FU, X.; SHAO, M.; BRENNAN, D.M.; ELLIS, S.G.; BRENNAN, M.; ALLAYEE, H.; LUSIS, A.J.; HAZEN, S.L. Relationship of paraoxonase 1 (PON 1) gene polymorphisms and functional activity with systemic oxidative stress and cardiovascular risk. JAMA., v.299, p.1265-1276, 2008.
BOEKHOLDT, S.M.; SACKS, F.M.; JUKEMA, J.W.; SHEPERD, J.; FREEMAN, D.J.; MCMAHON, A.D.; CAMBIEN, F.; NICAUD,V.; DE GROOTH, G.J.; TALMUD, P.J.; HUMPHRIES, S.E.; MILLER, G.J.; EIRIKSDOTTIR, G.; GUDNASON, V.; KAUMA, H.; KAKKO, S.; SAVOLAINEN, M.J.; ARCA, M.; MONTALI, A.; LIU, S.; LANZ, H.J.; ZWINDERMAN, A.H.; KUIVENHOVEN, J.A.; KASTELEIN, J.J. Cholesteryl ester transfer protein TaqIB variant, highdensity lipoprotein cholesterol levels, cardiovascular risk, and efficacy of pravastatin treatment: individual patient meta-analysis of 13677 subjects. Circulation, v.111, p.278287, 2005.

BOTELHO, P.B.; FIORATTI, C.O.; ABDALLA, D.S.P.; BERTOLAMI, M.C.; CASTRO, I.A. Classification of individuals with dyslipidaemia controlled by statins according to plasma biomarkers of oxidative stress using cluster analysis. Br. J. Nutr., v.103, p.256-265, 2010.

CHASMAN, D.I.; POSADA, D.; SUBRAHMANYAN, L.; COOK, N.R.; STANTON, V.P.; RIDKER, P. M. Pharmacogenetic study of statin therapy and cholesterol reduction. JAMA., v.291, p.2821-2827, 2004.

CHENG, G.W.; WU, H.L.; HUANG, Y.L. Simultaneous determination of malondialdehyde and ofloxacin in plasma using an isocratic high-performance liquid chromatography/ fluorescence detection system. Anal. Chim. Acta., v.616, p.230-234, 2008.

CHRZCZANOWICZ, J.; GAWRON, A.; ZWOLINSKA, A.; GRAFT-JOHNSON, J.; KRAJEWSKI, W.; KROL, M.; MARKOSWKI, J.; KOSTKA, T.; NOWAK, D. Simple method for determining human serum 2,2-diphenyl1-picryl-hydrazyl (DPPH) radical scavenging activity - possible application in clinical studies on dietary antioxidants. Clin. Chem. Lab. Med., v.46, p.342-349, 2008.

CRAWFORD, D.R.; DAVIES, K.J.A. Adaptive response and oxidative stress. Environ. Health Perspect., v.102, p.25$28,1994$.

DEVARAJ, S.; LEONARD, S.; TRABER, M.G.; JIALAL, I. Gamma tocopherol alone and in combination with alpha tocopherol decreases biomarkers of oxidative stress and inflammation in subjects with metabolic syndrome. FASEB $J .$, v.22, p.1103-1108, 2008. 
DONELLY, L.A.; DONEY, A.S.; DANNFALD, J.; WHITLEY, A.L.; LANG, C.C.; MORRIS, A.D.; DONNAN, P.T.; PALMER, C.N. A paucimorphic variant in the HMGCoA reductase gene is associated with lipid - lowering response to statin treatment in diabetes: a GoDARTS study. Pharmacogenet. Genomics, v.18, p.1021-1026, 2008.

FAULIN, T.E.S.; SENA, K.C.M.; TELLES, A.E.R.; GROSSO, D.M.; FAULIN, E.J.B.; ABDALLA, D.S.P. Validation of a novel ELISA for measurement of electronegative LDL. Clin. Chem. Lab. Med., v.46, p.1769-1775, 2008.

FRIEDWALD, W.T.; LEVY, R.; FREDRICKSON, D.S. Estimations of serum low density lipoprotein cholesterol without use of preparative ultracentrifuge. Clin. Chem., v.18, p.499-502, 1972.

JIALAL, I.; DEVARAJ, S. Scientific evidence to support a vitamin $\mathrm{E}$ and heart disease health claim: research needs. J. Nutr., v.135, p.348-353, 2005.

KAJINAMI, K.; TAKEKOSHI, N.; BROUSSEAU, M.E.; SCHAEFER, E.J. Pharmacogenetics of HMG-CoA reductase inhibitors:exploring the potential for genotypebased individualization of coronary heart disease management. Atherosclerosis, v.177, p.219-234, 2004.

KAUWELL, G.P. Emerging Concepts in nutrigenomics: A preview of what is to come. Nutr. Clin. Pract., v.20, p.75$87,2005$.

KOLOVOU, G.; DAMASKOS, D.; ANAGNOSTOPOULOU, K.; COKKINOS, D.V. Apolipoprotein E Gene polymosphism and gender. Ann. Clin. Lab. Sci., v.39, p.120-133, 2009.

KONTUSH, A.; CHANTEPIE, S.; CHAPMAN, M.J. Small, dense HDL particles exert potent protection of atherogenic LDL against oxidative stress. Arterioscler. Thromb. Vasc. Biol., v.23, p.1881-1888, 2003.

LAMBERT, J.C.; BROUSSEAU, T.; DEFOSSE, V.; EVANS, A.; ARVEILER, D.; RUIDAVETS, J.B.; HAAS, B.; CAMBOU, J.P.; LUC, G.; DUCIMETIÈRE, P.; CAMBIEN, F.; CHARTIER- HARLIN, M.C.; AMOUYEL, P. Independent association of an APOE gene promoter polymorphism with increased risk of myocardial infarction and decreased apoE plasma concentrations - The ECTIM study. Hum. Mol. Genet., v.9, p.57-61, 2000.
LIBBY, P.; RIDKER, P.M.; HANSSON, G.K. Progress and challenges in translating the biology of atherosclerosis. Nature, v.473, p.317-325, 2011.

LI, S.; DUDCZAK, R.; KOLLER, E.; BAGHESTANIAN, M.; GHANNADAN, M.; MINAR, E.; PIRICH, C.; ANGELBERGER, P.; VIRGOLINI, I.; LI, M.; VALENT, P. Effect of statins on lipoprotein receptor expression in cell lines from human mast cells and basophils. Eur. J. Clin. Pharmacol., v.59, p.507-516, 2003.

LIVAK, K.J.; FLOOD, S.J.; MARMARO, J.; GIUSTI, W.; DEETZ, K. Oligonucleotides with fluorescent dyes at opposite ends provide a quenched probe system useful for detecting PCR product and nucleic acid hybridization. $P C R$ Methods Appl., v.4, p.357-362, 1995.

LU, H.; INAZU, A.; MORIYAMA, Y.; HIGASHIKATA, T.; KAWASHIRI, M.; YU, W.; HUANG, Z.; OKAMURA, T.; MABUCHI, H. Haplotype analyses of cholesteryl ester transfer protein gene promoter: a clue to an unsolved mystery of TaqIB polymorphism. J. Mol. Med., v.81, p.246$255,2003$.

MAHLEY, R.W. Apolipoprotein E: cholesterol transport protein with expanding role in cell biology. Science, v.240, p.622630, 1988.

MILLER, S.A.; DYKES, D.D.; POLESKY, H.F. A simple salting out procedure for extracting DNA from human nucleated cells. Nucleic. Acids. Res., v.16, p.1215, 1988.

MORIKAWA, S.; UMETANI, M.; NAKAGAWA, S.; YAMAZAKI, H.; SUGANAMI, H.; INOUE, K.; KITAHARA, M.; HAMAKUBO, T.; KODAMA, T.; SAITO, Y. Relative induction of mRNA for HMG CoA reductase and LDL receptor by five different $\mathrm{HMG-CoA}$ reductase inhibitors in cultured human cells. J. Atheroscler. Thromb., v.7, p.138-144, 2000.

NEWTON, C.R.; GRAHAM, A.; HEPTINSTALL, L.E.; POWELL, S.J.; SUMMERS, C.; KALSHEKER, N.; SMITH, J.C.; MARKHAM, A.F. Analysis of any point mutation in DNA. The amplification refractory mutation system (ARMS). Nucleic Acids Res., v.17, p.2503-2516, 1989.

NG, C.J.; SHIH, D.M.; HAMA, S.Y.; VILLA, N.; NAVAB, M.; REDDY, S.T. The paraoxonase gene family and atherosclerosis. Free Radic. Biol. Med., v.38, p.153-163, 2005. 
PARTHASARATHY, S.; LITVINOV, D.; SELVARAJAN, K.; GARELNABI, M. Lipid peroxidation and decomposition - conflicting roles in plaque vulnerability and stability. Biochim. Biophys. Acta., v.1781, p.221-231, 2008.

PRIOR, R.L.; HOANG, H.; GU, L.; WU, X.; BACCHIOCCA, M.; HOWARD, L.; HAMPSCH-WOODILL, M.; HUANG, D.; OU, B.; JACOB, R. Assays for hydrophilic and lipophilic antioxidant capacity (oxygen radical absorbance capacity (ORACFL) of plasma and other biological and food samples. J. Agric. Food. Chem., v.51, p.3273-3279, 2003.

PROUDFOOT, J.M.; BARDEN, A.E.; LOKE, W.M.; CROFT, K.D.; PUDDEY, I.B.; MORI, T.A. (2009) HDL is the major lipoprotein carrier of plasma F2-isoprostanes. J. Lipid. Res., v.50, p.716-722, 2009.

RAINWATER, D.L.; RUTHERFORD, S.; DYER, T.D.; RAINWATER, E.D.; COLE, S.A.; VANDEBERG, J.L.; ALMASY, L.; BLANGERO, J.; MACCLUER, J.W.; MAHANEY, M.C. Determinants of variation in human serum paraoxonase activity. Heredity, v.102, p.147-154, 2009.

ROBERTS II, L.J.; OATES, J.A.; LINTON, M.F.; FAZIO, S.; MEADOR, B.P.; GROSS, M.D.; SHYR, Y.; MORROW, J.D. The relationship between dose of vitamin E suppression of oxidative stress in humans. Free Radic. Biol. Med., v.43, p.1388-1393, 2007.

ROBERTSON, K.S.; HAWE, E.; MILLER, G.J.; TALMUD, P.J.; HUMPHRIES, S.E. Human paraoxonase gene cluster polymorphisms as predictors of coronary heart disease risk in the prospective Northwick Park Heart Study II. Biochim. Biophys. Acta., v.1639, p.203-212, 2003.

SILUK, D.; OLIVEIRA, R.V.; ESTHER-RODRIGUEZROSAS, M.; LING, S.; BOS, A.; FERRUCCI, L.; WAINER, I.W. A validated liquid chromatography method for the simultaneous determination of vitamins A and $\mathrm{E}$ in human plasma. J. Pharm. Biomed. Anal., v.44, p.1001$1007,2007$.

STEINBERG, D.; PARTHASARATHY, S.; CAREW, T.E.; KHOO, J.C.; WITZTUM, J.L. Beyond cholesterol: modifications of low-density lipoprotein that increase its atherogenicity. N. Engl. J. Med., v.320, p.915-924, 1989.
STEPHENS, J.W.; BAIN, S.C.; HUMPHRIES, S.E. Gene- environment interaction and oxidative stress in cardiovascular disease. Atherosclerosis, v.200, p.229-238, 2008.

TANRIKULU, S.; ADEMOGLU, E.; GURDOL, F.; MUTLUTURKOGLU, U.; BILGE, A.K.; NISANCI, Y. Association of cholesteryl ester transfer protein $-629 \mathrm{C}>$ A polymorphism with high density lipoprotein cholesterol levels in coronary artery disease patients. Cell. Biochem. Funct., v.27, p.452457, 2009.

THOMPSON, A.; ANGELANTONIO, E.D.; SARWAR, N.; ERQOU, S.; SALEHEEN, D.; DULLAART, R.P.F.; KEAVNEY, B.Y.Z.; DANESH, J. Association of Cholesteryl Ester transfer protein genotypes with CETP Mass and activity, lipid levels and coronary risk. JAMA, v.299, p.2777-2788, 2008.

VAN ACKER, B.A.C.; BOTMA, G.; ZWINDERMAN, A.H.; KUIVENHOVEN, J.A.; DALLINGA-THIE, G.M.; SIJBRANDS, E.J.G.; BOER, J.M.A.; SEIDELL, J.C.; JUKEMA, J.W.; KASTELEIN, J.J.P.; JANSEN, H.; VERHOEVE, A.J.M. High HDL cholesterol does not protect against coronary artery disease when associated with combined cholesteryl ester transfer protein and hepatic lipase gene variants. Atherosclerosis, v.200, p.161-167, 2008.

VIIRI, L.E.; LOIMAALA, A.; NENONEN, A.; ISLAM, S.; VUORI, I.; KARHUNEN, P.J.; LEHTIMÄKI, T. The association of the apolipoprotein E gene promoter polymorphisms and haplotypes with serum lipid and lipoprotein concentrations. Atherosclerosis, v.179, p.161$167,2005$.

VIITANEN, L.; PIHLAJAMÃKI, J.; MIETTINEN, R.; KÃRKKÃINEN, P.; VAUHKONEN, I.; HALONEN, P.; KAREINEN, A.; LEHTO, S.; LAAKSO, M. Apolipoprotein E gene promoter $(-219 \mathrm{G} / \mathrm{T})$ polymorphism is associated with premature coronary heart disease. J. Mol. Med., v.79, p.732-737, 2001.

VIVEKANANTHAN, D.P.; PENN, M.S.; SAPP, S.K.; HSU, A.; TOPOL, E.J. Use of antioxidant vitamins for the prevention of cardiovascular disease:meta-analysis of randomized trials. Lancet, v.361, p.2017-2023, 2003. 
YE, S.; DUNLEAVEY, L.; BANNISTER, W.; DAY, L.B.; TAPPER, W.; COLLINS, A.R.; DAY, I.N.; SIMPSON, I. Independent effects of the $-219 \mathrm{G}>\mathrm{T}$ and epsilon 2/epsilon 3/epsilon 4 polymorphisms in the apolipoprotein E gene on coronary artery disease: the Southampton Atherosclerosis Study. Eur. J. Hum. Genet., v.11, p.437-443, 2003.

WITZTUM, J.L.; STEINBERG, D. The oxidative modification hypothesis of atherosclerosis: does it hold for humans? Trends Cardiovasc. Med., v.11, p.93-102, 2001.
ZEE, A.M.D.; KLUNGEL, O.H.; STRICKER, B.H.C.; VERSCHUREN, W.M.M.; KASTELEIN, J.J.P.; LEUFKENS, H.G.M.; BOER, A. Genetic polymorphism: importance for response to HMG-CoA reductase inhibitors. Atherosclerosis, v.163, p.213-222, 2002.

Received for publication on $15^{\text {th }}$ August 2011 Accepted for publication on $16^{\text {th }}$ January 2012 